\title{
Liming and macronutrient on early growth of Eucalyptus benthamii
}

\section{Diego Pereira da $\operatorname{Rosa}^{1}$ (D) Marcio Carlos Navroski $^{1^{*}}$ (i) Pedro Henrique Tavares da Fonseca ${ }^{1}$ (i) Mariane de Oliveira Pereira ${ }^{1}$ Eleandro José Brun ${ }^{2}$ (D) Jaiton Jaime das Neves Silva ${ }^{1}$ (ID}

${ }^{1}$ Departamento de Engenharia Florestal, Universidade do Estado de Santa Catarina (UDESC), 88504-600, Lages, SC, Brasil. E-mail: marcio.navroski@udesc.br. "Corresponding author.

${ }^{2}$ Programa de Pós-graduação em Agroecossistemas, Curso de Engenharia Florestal, Universidade Tecnológica Federal do Paraná (UTFPR), Dois Vizinhos, PR, Brasil.

ABSTRACT: Macronutrient suppression is one way to identify which chemical elements is the most important in the early development of seedlings offorest species. This study evaluated the initial growth of Eucalyptus benthamii seedlings through morphological and physiological variables, submitted to doses of $N, P$ and $K$, and liming. The experimental design to install the experiment was completely randomized, with a $2 \times 9$ factorial scheme, in which levels of factor " $A$ " referred to absence and presence of liming and levels of factor " $B$ ", to the different treatments of NPK. Morphological variables of SD (stem diameter) and H (height) and the physiological variables of $A$ (photosynthesis), E (transpiration), gs (stomatal conductance), $\mathrm{Ci} / \mathrm{Ca}$ (relationship between intercellular and atmospheric CO $\mathrm{C}_{2}$ concentration) and $\mathrm{WUE}$ (water use efficiency) were measured. For morphological variables, the absence of $N$ directly affected the means and there was a direct relationship between increase of the dose and increase of SD and $H$. There was a positive relationship of $P$ mainly in relation to shoot dry matter content (SDMC) and root dry matter content (RDMC). For the physiological variables, there was no direct response with the doses of $N$ or $P$, with $K$ being the element that most influenced the variables, especially when limestone was applied, resulting in higher averages for photosynthesis, transpiration and stomatal conductance. With the purpose of meeting the morphological and physiological demands, the recommendation for cultivation of Eucalyptus benthamii under the conditions of this study is the doses 150-200-150, without liming application.

Key words: omission of chemical element, initial development of seedlings, photosynthesis, stomatal conductance.

Calcário e macronutrientes no crescimento inicial de Eucalyptus benthamii

RESUMO: A supressão dos macronutrientes é uma das maneiras de identificar qual ou quais dos elementos químicos é o mais importante no desenvolvimento inicial das mudas de espécies florestais. O estudo objetivou avaliar o crescimento inicial de mudas de Eucalyptus benthamii por meio de variáveis morfológicas e fisiológicas, submetidas a doses de $N, P$ e $K$, e calagem. O delineamento experimental para instalação do experimento foi em delineamento inteiramente casualizado, com esquema fatorial $2 x 9$, em que os niveis do fator " $A$ " se referiram a ausência e a presença de calagem e os níveis do fator " $B$ ” aos diferentes tratamentos de NPK. Variáveis morfológicas de DAC (diâmetro a altura do colo) e H (altura) e as variáveis fisiológicas de A (fotossintese), E (transpiração), gs (condutância estomática), Ci/Ca (relação entre a concentração intercelular e atmosférica de $\mathrm{CO}_{2}$ ) e WUE (eficiência no uso da água) foram determinadas. Para as variáveis morfológicas, a ausência do $N$ afetou diretamente as médias, havendo uma relação direta entre o aumento da dose com o aumento das variáveis. Há uma relação positiva do P principalmente em relação a MSPA e MSPR. Para as variáveis fisiológicas, não houve resposta direta com as doses de $N$ ou $P$, sendo o Ko elemento que mais influenciou as variáveis, principalmente quando o calcário foi aplicado, resultando em maiores médias para fotossintese, transpiração e condutância estomática. Com o objetivo de atender às demandas morfológicas e fisiológicas, a recomendação para o cultivo de Eucalyptus benthamii nas condições deste estudo é a dose 150-200-150, sem aplicação de calagem.

Palavras-chave: omissão de elementos químicos, desenvolvimento inicial de mudas, fotossíntese, condutância estomática.

\section{INTRODUCTION}

Eucalyptus ranks among the most economically important trees globally (BAYLE et al., 2019). They exhibit traits, such as fast growth (LORENTZ \& MINOGUE, 2015) and high water and light use efficiency (MAIER et al., 2017), that contribute to their candidacy as an excellent biofuel crop (GONZALEZ et al., 2018). Most eucalypt species are native to Australia and Indonesia and are adapted to tropical and subtropical environments; however, some species have developed frost tolerance through advancements in biotechnology or adaptation (STANTURF et al., 2013). Eucalyptus benthamii 
has been shown to exhibit competitive frost tolerance when compared to members of the same genus (ARNOLD et al., 2015), making this species the most important currently in southern Brazil.

For the species to manifest its productive potential, it is necessary that the essential elements are available in the soil for absorption, given that the species originally occurs in fertile soils. In this sense, considering the low fertility of most Brazilian soils, liming and fertilization practices are essential to provide nutrients that are not in satisfactory concentrations to meet the demands of plants in the reforestation areas (SILVA et al., 2012).

Due to the fact that Brazilian soils do not have high fertility, there is a requirement for nutritional corrections, in which the fertilization method can be used. Thus, because it is a species with desirable characteristics, such as rapid growth, resistance to frost, good shape of the stem and rusticity, there is an increase in planting areas generating an increasing need for in-depth studies related to the relevant aspects for the species and its production (CUNHA et al., 2019).

When the nutritional requirements of the species are known, it is possible to identify and correct their needs in the soil, as nutrients have essential and specific functions in the metabolism of plants. Thus, when one of the essential elements are not present in satisfactory quantities or in conditions that make it poorly available, its deficiency promotes changes in the plant's metabolism. The symptoms of mineral deficiencies are more or less characteristic for each nutrient, species/cultivar and environmental factors (PRADO et al., 2010).

The lack of essential nutrients for plants such as nitrogen, phosphorus and potassium can represent a drastic decrease in growth and productivity. Nitrogen is one of the mineral elements most demanded by plants, and plants grown under inadequate amounts of $\mathrm{N}$ do not fully express their genetic potential, with a series of morphophysiological changes, negatively affecting the development of crops (MATOS et al., 2011 ). Likewise, plants with a deficiency in phosphorus and potassium have retarded growth, as they are affected by processes such as protein synthesis, nucleic acids, and reduction of highenergy storage compounds, such as ATP (Adenosine Triphosphate). It is through the use of this energy that the plant performs photosynthesis, actively absorbs nutrients from the soil and synthesizes various organic compounds (VIÉGAS et al., 2011).

One of the methods to identify the most needed nutrients for a given species and the symptoms it may show in the case of a nutrient deficiency is the missing element technique. Given this assumption, the general objective of the study was to evaluate the effect of doses of N, P and K, as well as liming on the initial growth of Eucalyptus benthamii seedlings through morphological and physiological variables.

\section{MATERIALS AND METHODS}

The study was carried out in forest nursery of the State University of Santa Catarina, located in Lagos, southern Brazil (coordinates 2747'33'S and $50^{\circ} 18^{\prime} 4^{\prime \prime} \mathrm{W}$ ), with an altitude of approximately 900 meters. The experiment was conducted in a greenhouse with a 150 micron plastic cover, with an average temperature of $25-30{ }^{\circ} \mathrm{C}$ and humidity between 65 and $90 \%$. According to the Köeppen classification, the climate of Lages/SC is humid mesothermal with mild summer (temperate $\mathrm{Cfb}$ ). The average annual temperature is $15^{\circ} \mathrm{C}$ and the average annual rainfall is 1300 to $1500 \mathrm{~mm}$ (ALVARES et al., 2013). The implementation of the experiment occurred in early January 2018.

The soil used to fill the pots consisted of soil taken from a depth from 0 to $50 \mathrm{~cm}$ from a Humic Cambisol (World Reference Base - WRB/FAO systems). The physical and chemical soil analysis are: $\mathrm{pH}=4.7 \mathrm{H}_{2} \mathrm{O}^{2}$; SMP Index $=4.90 ; \mathrm{Ca}^{(2)}=2.2 \mathrm{cmol}$ $\mathrm{dm}^{-3} ; \mathrm{Mg}^{(2)}=1.2 \mathrm{cmol} \mathrm{dm}_{\mathrm{c}}^{-3} ; \mathrm{Al}^{(2)}=4.9 \mathrm{cmol} \mathrm{dm}_{\mathrm{c}}^{-3} ; \mathrm{P}$ Mehlich $^{(2)}=3.7 \mathrm{mg} \mathrm{dm}^{-3} ; \mathrm{K}^{(2)}=48 \mathrm{mg} \mathrm{dm}^{-3}$; organic matter - $\mathrm{OM}=2.9 \%$; Effective $\mathrm{CEC}=6.46 \mathrm{cmol}_{\mathrm{c}} \mathrm{dm}^{-3}$; CEC $\mathrm{pH} 7.0=13.1 \mathrm{cmol}_{\mathrm{c}} \mathrm{dm}^{-3}$; Base saturation $=26.8 \%$; Al saturation $=58.2 \%$; clay $=47.6 \%$, silt $=24.4 \%$ and sand $=28 \%$.

The seedlings of seminal origin of Eucalyptus benthamii were obtained from the forest nursery of the region, with approximately 120 days. They presented an adequate development for field planting, that is, a height close to $25 \mathrm{~cm}$, between 4-5 pairs of leaves and $2 \mathrm{~mm}$ of root collar diameter, as recommended by NAVROSKI et al. (2015).

The experiment was conducted in a completely randomized design in a $2 \times 9$ factorial scheme. The factor " $\mathrm{A}$ " consists of presence or absence of limestone $\left(0.865 \mathrm{~g} \mathrm{~kg}^{-1}\right.$ PRNT $\left.70 \%\right)$ and the factor "B", combinations of nutrients $\left(\mathrm{mg} \mathrm{kg}{ }^{-1}\right)$, $\mathrm{N}$ (nitrogen), $\mathrm{P}$ (phosphorus) and $\mathrm{K}$ (potassium): T1: 0-0-0; T2: 0-200-150; T3: 150-0-150; T4: 150200-0; T5: 150-200-150; T6: 150-200-300; T7: 150-400-150; T8: 300-200-150; and; T9: 300-400300. The determination of the liming treatments and doses of NPK followed the recommendation of MAEDA \& BONOLA (2012) and ROS et al. (2016), 
assuming 150-200-150 as the recommended dosage according to the nutrients used in the present study. The treatments (NPK dosages) were then assembled in which each chemical element was omitted, the recommended dose and twice the recommended dose.

To compose the treatments, the nutrient formulations used were: $\mathrm{N}$ : $45 \%$ urea; $\mathrm{P}: 42 \%$ $\mathrm{P}_{2} \mathrm{O}_{5}$ TSP (triple superphosphate); and $\mathrm{K}: 60 \% \mathrm{KCl}$ (potassium chloride). Each treatment consisted of 10 repetitions (pots) of a plant, given that each pot had a capacity of $5 \mathrm{~L}$. The pots had five holes in the base for draining irrigation water. The nutrients were weighed in analytical balance and separated in single doses for $\mathrm{K}$ and $\mathrm{P}$. N was applied in six installments, every 15 days. The respective doses of $\mathrm{N}$ were diluted in distilled water, by mixing for 30 minutes and after being applied to the plants.

Initially the soil was spread on a plastic tarp inside the greenhouse and subjected to constant revolving for nutrient incorporation. Subsequently, the pots were filled with $5 \mathrm{~kg}$ of soil and placed in a location with the same intensity of irrigation and luminosity (solar energy). After filling the pots, the seedlings were transplanted, and a manual hole of approximately $300 \mathrm{~cm}^{3}$ was opened in the center of each pot for planting. The irrigation in the greenhouse was carried out with micro-sprinklers, with four daily irrigations (9:00 am; 12:00 pm; 3:00 pm; 6:00 pm) of approximately 8 daily $\mathrm{mm}$ of water. The water used for irrigation of the experiment is the same as that used in the nursery, being originally from an artesian well at the university.

\section{Morphological variables}

Height and diameter biometric assessments were performed every 30 days for 4 months, and an initial assessment was performed at the time of the experiment implementation. The height of the seedlings $(\mathrm{cm})$ was determined with the aid of a millimeter ruler or tape measure, measuring from the base of the plant to the insertion of the highest leaf. The stem diameter (ST) was measured in $\mathrm{mm}$ and determined with the aid of a digital caliper $\left(\right.$ Digimess $^{\circledR}$ ) with $0,01 \mathrm{~mm}$ of resolution. After the data collection period, the manual collection of the total biomass of the plants was held by a destructive method. The samples were separated into root dry matter content (RDMC) and shoot dry matter content (SDMC). They were stored in paper bags kept in a forced air circulation oven $\left(65 \pm 3{ }^{\circ} \mathrm{C}\right)$ and weighed every $8 \mathrm{~h}$ until constant mass was obtained. After $36 \mathrm{~h}$, when the constant mass $(\mathrm{g})$ was reached, the dry matter contents of the components were determined in precision balance $(0.01 \mathrm{~g})$ and the Dickson quality indexes were calculated. The Dickson quality index - DQI (DICKSON et al., 1960) is a tool to evaluate seedling quality as a function of total dry matter, shoot height, stem diameter, shoot dry matter - sum of stem base dry matter and leaf dry matter - and root dry matter.

\section{Gas exchange}

Gas exchange evaluations were performed with the aid of a portable photosynthesis system - InfraRed Gas Analyzer - IRGA (Licor, model Li-6400XT, United State) in 4 repetitions, where the values for photosynthesis $(A)$, stomatal conductance $(g s)$, transpiration $(E)$, relationship between intercellular and atmospheric $\mathrm{CO}_{2}$ concentration $(\mathrm{Ci} / \mathrm{Ca})$ and water use efficiency ( $W U E$ ) determined by the ratio of $A$ by $E$ were determined. The photosynthetically active radiation used during measurements was 800 $\mu$ mol photons $\mathrm{m}^{2} \mathrm{~s}^{-1}$. This value was determined by the light saturation curve measured for eucalyptus, ranging between 800 and $1000 \mu \mathrm{mol}$ of photons $\mathrm{m}^{-2} \mathrm{~s}^{-1}$ (SILVA et al., 2000). Gas exchange evaluations for $E$. benthamii species of seminal origin were performed at 4 months after the last collection of growth data. For this evaluation, the same plant and the same leaf of each repetition was used, and the treatments were evaluated sequentially so that all treatments were covered in the same period of light of the day. The evaluations were always carried out between 7:00 and 9:30 am, being that the readings were stable in 2-3 minutes, when recorded by the equipment.

\section{Statistical analyses}

The treatment variances were tested for homogeneity by the Bartlett test. When there was homogeneity of variances, the data was subjected to analysis of variance and when there was a significant difference by the F test, the Scott-Knott's at the $5 \%$ probability level. When necessary, the data were transformed with a boxcox test. The analyzes were performed with the Sisvar statistical software (FERREIRA, 2019).

\section{RESULTS}

\section{Morphological variables}

For the SD variable, the results comparing the factors with and without liming had a statistical difference in the dose 300-200-150 (N-P-K), presenting a mean for the factor without liming $26 \%$ higher when compared to the factor with liming (Table 1). Another difference was reported in the 150-200-300 (N-P-K), where the factor without 
Table 1 - Means of the variables SD (stem diameter $-\mathrm{mm}$ ), H (height $-\mathrm{cm}$ ), HD (relationship between SD and H), shoot dry matter content (SDMC), root dry matter content (RDMC) and Dickson Quality Index (DQI) for Eucalyptus benthamii at 120 days.

\begin{tabular}{|c|c|c|c|c|c|c|}
\hline \multirow[t]{3}{*}{$\begin{array}{l}\text { Treatment } \\
\text { N-P-K }\left(\mathrm{mg} \mathrm{kg}^{-1}\right)\end{array}$} & \multicolumn{2}{|c|}{------------SD (mm)------------ } & \multicolumn{2}{|c|}{--------------------H (cm)----------------- } & \multicolumn{2}{|c|}{ 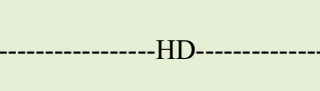 } \\
\hline & \multicolumn{6}{|c|}{ 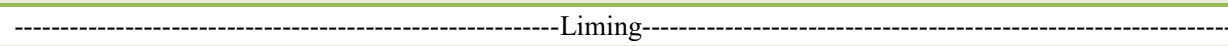 } \\
\hline & without & with & without & with & without & with \\
\hline $0-0-0$ & $7.1 \mathrm{Ab}^{*}$ & $6.3 \mathrm{Ac}$ & $87.0 \mathrm{Ac}$ & $72.8 \mathrm{Ab}$ & $12.4 \mathrm{Aa}$ & $11.8 \mathrm{Aa}$ \\
\hline $0-200-150$ & $7.8 \mathrm{Ab}$ & $8.4 \mathrm{Ab}$ & $103.8 \mathrm{BC}$ & $78.4 \mathrm{Bb}$ & $13.5 \mathrm{Aa}$ & $9.4 \mathrm{Ba}$ \\
\hline $150-0-150$ & $7.2 \mathrm{Ab}$ & $8.2 \mathrm{Ab}$ & $96.2 \mathrm{Ac}$ & $85.4 \mathrm{Bb}$ & $14.0 \mathrm{Aa}$ & $10.9 \mathrm{Ba}$ \\
\hline $150-200-0$ & $9.5 \mathrm{Aa}$ & $8.9 \mathrm{Ab}$ & $125.0 \mathrm{Ab}$ & 111.6 Aa & 13.2 Aa & $12.7 \mathrm{Aa}$ \\
\hline $150-200-150$ & $9.5 \mathrm{Aa}$ & $10.1 \mathrm{Aa}$ & $139.8 \mathrm{Aa}$ & $91.6 \mathrm{Bb}$ & $15.0 \mathrm{Aa}$ & $9.1 \mathrm{Ba}$ \\
\hline $150-200-300$ & $8.7 \mathrm{Bb}$ & $11.1 \mathrm{Aa}$ & $103.8 \mathrm{Bc}$ & $122.4 \mathrm{Aa}$ & $12.2 \mathrm{Aa}$ & $11.1 \mathrm{Aa}$ \\
\hline $150-400-150$ & $10.6 \mathrm{Aa}$ & $9.1 \mathrm{Ab}$ & $124.8 \mathrm{Ab}$ & $87.2 \mathrm{Bb}$ & $11.9 \mathrm{Aa}$ & $9.7 \mathrm{Aa}$ \\
\hline $300-200-150$ & $11.7 \mathrm{Aa}$ & $8.6 \mathrm{Bb}$ & $148.4 \mathrm{Aa}$ & $87.0 \mathrm{Bb}$ & $12.8 \mathrm{Aa}$ & $10.2 \mathrm{Ba}$ \\
\hline $300-400-300$ & $9.4 \mathrm{Aa}$ & $9.8 \mathrm{Aa}$ & $108.8 \mathrm{Ac}$ & $92.2 \mathrm{Ab}$ & $11.7 \mathrm{Aa}$ & $9.9 \mathrm{Aa}$ \\
\hline \multirow{3}{*}{$\begin{array}{l}\text { Treatment } \\
\text { N-P-K }\left(\mathrm{mg} \mathrm{kg}^{-1}\right)\end{array}$} & \multicolumn{2}{|c|}{-------------SDMC (g)------------ } & \multicolumn{2}{|c|}{ 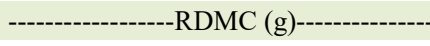 } & \multicolumn{2}{|c|}{--------------------DQI-------------. } \\
\hline & \multicolumn{6}{|c|}{ 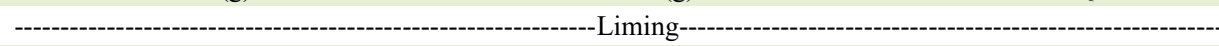 } \\
\hline & without & with & without & with & without & with \\
\hline $0-0-0$ & $10.8 \mathrm{Ad}^{*}$ & $9.6 \mathrm{Ab}$ & $7.2 \mathrm{Ab}$ & $4.4 \mathrm{Ab}$ & $1.38 \mathrm{Ab}$ & $1.04 \mathrm{Ab}$ \\
\hline $0-200-150$ & $14.4 \mathrm{Ad}$ & $15.2 \mathrm{Ab}$ & $4.8 \mathrm{Ab}$ & $10.4 \mathrm{Ab}$ & $1.22 \mathrm{Ab}$ & $2.34 \mathrm{Ab}$ \\
\hline $150-0-150$ & $16.8 \mathrm{Ad}$ & $13.2 \mathrm{Ab}$ & $6.8 \mathrm{Ab}$ & $5.2 \mathrm{Ab}$ & $1.55 \mathrm{Ab}$ & $1.47 \mathrm{Ab}$ \\
\hline $150-200-0$ & $27.6 \mathrm{Ac}$ & $25.4 \mathrm{Aa}$ & $12.4 \mathrm{Ab}$ & $10.0 \mathrm{Ab}$ & $2.62 \mathrm{Ab}$ & $2.44 \mathrm{Ab}$ \\
\hline $150-200-150$ & $28.8 \mathrm{Ac}$ & $32.4 \mathrm{Aa}$ & $13.6 \mathrm{Ab}$ & $16.0 \mathrm{Aa}$ & $2.60 \mathrm{Bb}$ & $4.35 \mathrm{Aa}$ \\
\hline $150-200-300$ & $22.0 \mathrm{Bc}$ & $34.4 \mathrm{Aa}$ & $10.0 \mathrm{Bb}$ & $20.0 \mathrm{Aa}$ & $2.30 \mathrm{Bb}$ & $4.28 \mathrm{Aa}$ \\
\hline $150-400-150$ & $35.2 \mathrm{Ab}$ & $26.8 \mathrm{Aa}$ & 17.6 Aa & $10.4 \mathrm{Ab}$ & $3.78 \mathrm{Aa}$ & $3.10 \mathrm{Aa}$ \\
\hline $300-200-150$ & $52.4 \mathrm{Aa}$ & $19.6 \mathrm{Bb}$ & $23.6 \mathrm{Aa}$ & $10.4 \mathrm{Bb}$ & $5.15 \mathrm{Aa}$ & $2.46 \mathrm{Bb}$ \\
\hline $300-400-300$ & $28.4 \mathrm{Ac}$ & $25.6 \mathrm{Aa}$ & $10.8 \mathrm{Ab}$ & $13.2 \mathrm{Aa}$ & $2.83 \mathrm{Ab}$ & $3.79 \mathrm{Aa}$ \\
\hline
\end{tabular}

*Means followed by the same letter, lowercase letters in the column and uppercase letters in the row for each variable do not differ from each other by the Scott-Knott's test at $5 \%$ probability.

liming obtained a mean $22 \%$ higher when compared to the one with liming. Considering the factor without liming, when comparing the NPK doses, the highest mean was obtained by $300-200-150$ and was not statistically different from $150-200-150 ; 150-400$ 150; 150-200-0; and 300-400-300. Considering the factor with liming, the treatment with highest mean was 150-200-300 and was not statistically different from 150-200-150 and 300-400-300. The treatment with the lowest mean was the dose 0-0-0.

The highest average height was observed for $300-200-150$, in the factor without liming, $41 \%$ greater than the average factor with liming for the same treatment. Unfolding the NPK dosages within the factor without liming, the highest mean height was observed for 300-200-150 which was not statistically different from $150-200-150$, but $41 \%$ greater than the lowest average (0-0-0). In the liming factor, the highest average was 150-200-300, which did not differ from $150-200-0$, and was $40 \%$ higher than the lowest average (0-0-0). Only the dosage 150-200300 showed a lower average for the lack of liming when compared to the liming treatment. The other treatments showed no difference with the application of lime or showed higher averages without liming.

Plants grown in doses 150-200-150; 0-200150; 300-200-150; and 150-0-150 obtained higher values of the HD ratio for the factor without liming when compared to those with liming. The highest mean was observed for 150-200-150 treatment without liming, differing by $39 \%$ when compared to the same treatment with liming. Among the factors, no statistical differences were obtained for the means, without or with liming.

The higher mean to SDM was observed when comparing the liming factor for the dosage $300-200-150$ without liming, which was $63 \%$ higher than the same treatment with liming (Table 1). The treatment 150-200-300 with liming was superior to the one without liming by $36 \%$. When comparing 
the results within the factor without liming, the 300200-150 treatment obtained the highest mean, being $79 \%$ higher than the 0-0-0 treatment that obtained the lowest mean. Considering the liming factor, the highest mean was observed for the 150-200-300 treatment.

Similar results were observed for SDMC and RDMC when comparing the factors with liming. There was statistical difference for the dosage 300200-150, and in the factor without liming the mean was $56 \%$ higher than in the factor with liming. In the unfolding of NPK dosage within the liming factor, the highest mean without liming was obtained for 300-200$150,71 \%$ higher than the mean of 150-0-150 (lowest mean). In the NPK dosage with liming the highest mean was 150-200-300. The lowest mean for the factor with liming was in the dosage $0-0-0$, which was $78 \%$ lower when compared to the highest mean observed.

For Dickson Quality Index (DQI), the NPK dosage 300-200-150 without liming presented a higher mean than the same treatment with liming, being 52\% higher. The dosage 150-200-150 and 150200-300 without liming were 40 and $46 \%$ lower, respectively, when compared to their respective with liming. Within the factor without liming, the dosage 300-200-150 obtained highest mean, whereas with liming the highest mean was obtained for 150-200150. The lowest mean with liming was observed in the dosage $0-0-0$, which was $76 \%$ lower than the highest mean NPK dosage.

\section{Physiological variables}

For variable $A$, the only NPK dosage that had no statistical difference between the liming factor was the 150-200-150; there were differences among the other treatments (Table 2). For the liming factor, the treatment of highest mean was the dosage 150-2000 . Considering the factor without liming, the highest mean was for $0-200-150$, which was higher in $46 \%$ than the dosage with lowest mean (300-400-300).

The NPK dosage 0-200-150; 150-0150; and 150-200-300 without liming had higher means - 29\%, 36 and $28 \%$, respectively - when compared to the same treatments with liming to the transpiration $(E)$. The mean of dosage $0-0-0$ and 300-400-300 with liming were higher and statistically differed from the same treatments without liming. In the unfolding of NPK dosage within the factor without liming, the highest mean was presented by 0-200-150 and was $64 \%$ higher than the dosage of lowest mean (300-400-300). In the liming factor, the highest mean was for 150-200-0, higher in 54\% of the dosage of lowest means (300-200-150 and 150-0-150).
For the variable stomatal condutance $(\mathrm{gs})$, the NPK dosage $0-0-0 ; 300-200-150 ; 150-400-150 ; 150$ 200-0; 150-200-300 and 300-400-300 with liming had higher means and differed statistically from the same treatments without liming. Within the factor without liming the highest mean obtained was for 0-200-150, $77 \%$ higher than the lowest mean (300-400-300). In the factor with liming the highest mean was obtained for 150-200-0 which differed statistically from the other treatments. The lowest mean was observed in 300-400-300, which was not statistically different from 300-200-150 and 150-0-150 and was 52\% lower compared to the dosage of highest mean.

In general, the factor with liming obtained the highest means of $\mathrm{Ci} / \mathrm{Ca}$. The greatest difference occurred in dosage 300-400-300, which presented a $34 \%$ higher value compared to treatment without liming. There was no statistical difference between the factors without and with liming for dosage 0-200$150 ; 150-0-150$ and $150-400-150$ to $\mathrm{Ci} / \mathrm{Ca}$. For the presence of liming, the dosage $0-0-0$ showed the highest average of $\mathrm{Ci} / \mathrm{Ca}$. The lowest averages were obtained in treatments with higher N (300-200-150 and 300-400-300). In the unfolding of treatments within the factor without liming the highest mean was observed for $0-200-150,39 \%$ higher compared to the dosage of lowest mean (300-400-300). The lowest mean was observed in dosage 300-200-150 which did not differ statistically from 300-400-300 and was $25 \%$ lower than the treatment of highest mean.

The NPK dosage 0-0-0 and 300-400-300 without liming, were superior to those with liming to water use efficiency (WUE). In the unfolding of treatments within the factor without liming the highest mean was observed in dosage 300-400-300, $36 \%$ higher than the lowest average (0-200-150). For the liming factor, the highest mean was in the dosage $300-200-150$, the lowest mean was observed for $0-0-0$ which differed from the other treatments and was $44 \%$ lower compared to the treatment of highest mean.

\section{DISCUSSION}

\section{Morphological variables}

For morphological variables, the results of treatments with $\mathrm{N}$ or $\mathrm{P}$ omission are the most affected, showing reduction in $\mathrm{SD}, \mathrm{H}, \mathrm{SDMC}$ and RDMC when compared with treatments with these nutrients. The decrease in growth in plants with low nitrogen, as observed in our study with $E$. benthamii is a function of the element's participation in the structure of numerous molecules, being the main limitation of growth, as it is part of proteins, nucleic acids and 
Table 2 - Means of variables $A$ (photosynthesis $\left.-\mu \mathrm{mol} \mathrm{m} \mathrm{m}^{-2} \mathrm{~s}^{-1}\right), E$ (transpiration $-\mathrm{mmol}$ of $\mathrm{H}_{2} \mathrm{O} \mathrm{m}^{-2} \mathrm{~s}^{-1}$ ), gs (stomatal condutance - mmol of $\mathrm{H}_{2} \mathrm{O} \mathrm{m}^{-2} \mathrm{~s}^{-1}$ ) $\mathrm{ci} / \mathrm{ca}$ (ratio between intercellular and atmospheric $\mathrm{CO}_{2}$ concentration $-\mu \mathrm{mol} \mu \mathrm{mol}^{-1}$ ), and WUE (water use efficiency) for Eucalyptus benthamii at 120 days.

\begin{tabular}{|c|c|c|c|c|c|c|}
\hline \multirow{4}{*}{$\begin{array}{l}\text { Treatment } \\
\text { N-P-K } \\
\left(\mathrm{mg} \mathrm{kg}^{-1}\right)\end{array}$} & \multirow{2}{*}{\multicolumn{2}{|c|}{---------- $A\left(\mu \mathrm{mol} \mathrm{m}{ }^{-2} \mathrm{~s}^{-1}\right)$---------- }} & \multirow{2}{*}{\multicolumn{2}{|c|}{-------- $E\left(\mathrm{mmol}\right.$ of $\left.\mathrm{H}_{2} \mathrm{O} \mathrm{m}^{-2} \mathrm{~s}^{-1}\right)------$}} & \multirow{2}{*}{\multicolumn{2}{|c|}{-----gs $\left(\mathrm{mmol}\right.$ of $\left.\mathrm{H}_{2} \mathrm{O} \mathrm{m}^{-2} \mathrm{~s}^{-1}\right)----$}} \\
\hline & & & & & & \\
\hline & \multicolumn{6}{|c|}{ 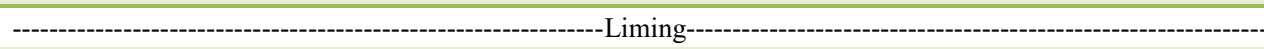 } \\
\hline & without & with & without & with & without & with \\
\hline $0-0-0$ & $7.47 \mathrm{Ac}^{*}$ & $5.97 \mathrm{Be}$ & $1.88 \mathrm{Bc}$ & $2.40 \mathrm{Ab}$ & $0.13 \mathrm{Bd}$ & $0.19 \mathrm{Ab}$ \\
\hline $0-200-150$ & $10.86 \mathrm{Aa}$ & $9.61 \mathrm{Bc}$ & $3.37 \mathrm{Aa}$ & $2.39 \mathrm{Bb}$ & $0.22 \mathrm{Aa}$ & $0.20 \mathrm{Ab}$ \\
\hline $150-0-150$ & $8.60 \mathrm{Ab}$ & $7.56 \mathrm{Bd}$ & $2.46 \mathrm{Ab}$ & $1.57 \mathrm{Bc}$ & $0.12 \mathrm{Ad}$ & $0.12 \mathrm{Ad}$ \\
\hline $150-200-0$ & $8.93 \mathrm{Bb}$ & $12.52 \mathrm{Aa}$ & $2.45 \mathrm{Bb}$ & $3.39 \mathrm{Aa}$ & $0.12 \mathrm{Bd}$ & $0.25 \mathrm{Aa}$ \\
\hline $150-200-150$ & $9.60 \mathrm{Ab}$ & $9.44 \mathrm{Ac}$ & $2.11 \mathrm{Ac}$ & $2.05 \mathrm{Ac}$ & $0.15 \mathrm{Ac}$ & $0.17 \mathrm{Ab}$ \\
\hline $150-200-300$ & $10.14 \mathrm{Aa}$ & $7.64 \mathrm{Bd}$ & $3.35 \mathrm{Aa}$ & $2.41 \mathrm{Bb}$ & $0.18 \mathrm{Ab}$ & $0.16 \mathrm{Ac}$ \\
\hline $150-400-150$ & $8.90 \mathrm{Bb}$ & $10.43 \mathrm{Ab}$ & $2.90 \mathrm{Ab}$ & $2.55 \mathrm{Ab}$ & $0.15 \mathrm{Bc}$ & $0.20 \mathrm{Ab}$ \\
\hline $300-200-150$ & $6.77 \mathrm{Bc}$ & $9.00 \mathrm{Ac}$ & $1.51 \mathrm{Ad}$ & $1.57 \mathrm{Ac}$ & $0.10 \mathrm{Be}$ & $0.13 \mathrm{Ad}$ \\
\hline $300-400-300$ & $5.82 \mathrm{Bd}$ & $8.86 \mathrm{Ac}$ & $1.21 \mathrm{Bd}$ & $1.93 \mathrm{Ac}$ & $0.05 \mathrm{Bf}$ & $0.12 \mathrm{Ad}$ \\
\hline \multirow{3}{*}{$\begin{array}{l}\text { Treatment } \\
\text { N-P-K } \\
\left(\mathrm{mg} \mathrm{kg}^{-1}\right)\end{array}$} & \multicolumn{4}{|c|}{--------------------Ci/Ca $\left(\mu \mathrm{mol} \mu \mathrm{mol}^{-1}\right)-------------------$} & ---------. & 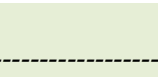 \\
\hline & \multicolumn{6}{|c|}{----------------------------------------------------------Liming--------------------------------------------------------------' } \\
\hline & \multicolumn{2}{|r|}{ without } & \multicolumn{2}{|l|}{ with } & Without & with \\
\hline $0-0-0$ & & $0.67 \mathrm{Bb}^{*}$ & \multicolumn{2}{|l|}{$0.83 \mathrm{Aa}$} & $4.10 \mathrm{Ab}$ & $3.21 \mathrm{Bd}$ \\
\hline $0-200-150$ & & $0.75 \mathrm{Aa}$ & \multicolumn{2}{|l|}{$0.75 \mathrm{Ab}$} & $3.40 \mathrm{Bc}$ & $4.20 \mathrm{Ac}$ \\
\hline $150-0-150$ & & $0.65 \mathrm{Ab}$ & \multicolumn{2}{|l|}{$0.68 \mathrm{Ac}$} & $4.01 \mathrm{Bb}$ & $4.90 \mathrm{Ab}$ \\
\hline $150-200-0$ & & $0.63 \mathrm{Bc}$ & \multicolumn{2}{|l|}{$0.74 \mathrm{Ab}$} & $3.95 \mathrm{Ab}$ & 4.17 Ac \\
\hline $150-200-150$ & & $0.61 \mathrm{Bc}$ & \multicolumn{2}{|l|}{$0.71 \mathrm{Ac}$} & $4.90 \mathrm{Aa}$ & $5.35 \mathrm{Aa}$ \\
\hline $150-200-300$ & & $0.67 \mathrm{Bb}$ & \multicolumn{2}{|l|}{$0.72 \mathrm{Ac}$} & $3.49 \mathrm{Bc}$ & $4.11 \mathrm{Ac}$ \\
\hline $150-400-150$ & & $0.69 \mathrm{Ab}$ & \multicolumn{2}{|l|}{$0.71 \mathrm{Ac}$} & $3.53 \mathrm{Bc}$ & $4.47 \mathrm{Ac}$ \\
\hline $300-200-150$ & & $0.57 \mathrm{Bd}$ & \multicolumn{2}{|l|}{$0.62 \mathrm{Ad}$} & $4.95 \mathrm{Ba}$ & $5.76 \mathrm{Aa}$ \\
\hline $300-400-300$ & & $0.46 \mathrm{Be}$ & \multicolumn{2}{|l|}{$0.65 \mathrm{Ad}$} & $5.30 \mathrm{Aa}$ & $4.80 \mathrm{Bb}$ \\
\hline
\end{tabular}

*Means followed by the same letter, lowercase letters in the column and uppercase letters in the row for each variable do not differ from each other by the Scott-Knott's test at 5\% probability.

many other cellular constituents, such as membranes and hormones (SOUZA \& FERNANDES, 2006). Phosphorus is also crucial in plant metabolism, since that acts in the transfer of energy in the cell, in the respiratory rate, photosynthesis, composes structures of nucleic acids, genes, chromosomes as well as several coenzymes (MENEGHETTE et al., 2017).

According to VIEIRA et al. (2016), in a similar investigation with macronutrient suppression, with the omission of $\mathrm{N}$ there was a significant reduction in plant growth, especially in relation to shoot and root dry matter contents. According to the authors, this reduction in growth in omission to $\mathrm{N}$ is expected because, in general, this is the most required element in the early stage of development. According to SMETHURST et al. (2004), the greatest need for
$\mathrm{N}$ is in the first two years of the cycle. ROS et al. (2016), when studying initial growth of E. grandis with macronutrient suppression, observed that there were significant reductions in height and diameter at breast height with $\mathrm{N}$ suppression.

As noted in the present study, E. benthamii is highly responsive to phosphate fertilization. This same behavior was observed by DIAS et al. (2014) in which the highest dose of P (300 kg ha $\left.{ }^{-1}\right)$ caused an increase of 2.6 times in the diameter of the neck, 1.1 times in the height of the plants and 9.9 times in the volume of wood per hectare, in relation to the control. The responses to phosphate fertilization of $E$. benthamii were superior to $E$. dunnii in the experiment, which was evaluated 11 months after planting in the field. 
For all variables, the treatment that presents the highest mean in the absence of liming is the one that hase twice the value of the dose recommended for $\mathrm{N}$ (300-200-150). Conversely, in the treatments with liming, the highest means are presented in the treatments with twice the dose of $\mathrm{K}$ and the recommended for $\mathrm{N}$ and $\mathrm{P}$ (150-200-300). Even so, there is a significant reduction in the mean of treatments with absence of $\mathrm{N}$ and $\mathrm{P}$. In treatments with suppression of $\mathrm{K}$ only, both for presence and absence of liming, the result for the morphological variables is not affected. There seems to be a greater dependence on $\mathrm{N}$ to liming, and less effect on $\mathrm{P}$ and $\mathrm{K}$. Positive effect of liming on decreasing $\mathrm{N}$ application was observed by WYNGAARD et al. (2012), when liming was not performed, there was a need for an increase in N. According to our results, when liming was not performed, in the absence of $\mathrm{N}$ and $\mathrm{P}$, there is also a significant reduction in the means of the morphological variables, also showing an effect on P. Possibly the omission of only $\mathrm{K}$ did not present a harmful effect because the soil used (in the region) presented values within what is considered ideal for the genus Eucalyptus (MALAVOLTA et al., 1997).

The absence of $\mathrm{P}$ significantly affected the results for both treatments, without and with liming. STAHL et al. (2013) stated that the addition of P to soil increases the production of shoot and root dry matter contents of $E$. benthamii in pots. The production of shoot dry matter content (SDMC) is significantly influenced by the application of $\mathrm{P}$ doses in soil (MAEDA \& BONOLA, 2012). There is usually a reduction in plant growth with $\mathrm{P}$ suppression, as it is the most limiting nutrient, due to the naturally low levels and the high $\mathrm{P}$ adsorption capacity of most soils in tropical regions (NOVAIS et al., 2007). In addition, the reduction in plant growth due to $\mathrm{P}$ suppression occurs with greater intensity in young stands (GAVA, 1997). Very high doses of NPK, as in the treatment (300-400-300) also did not show a favorable response, suggesting that using large amounts of nutrients is unfeasible. In addition to being economically unviable, it can also cause contamination of the environment. This result may also be related to the cultivation environment being pots, and not the field environment. In the pots, there is a higher root/soil ratio compared to plants grown in the field. In pots, the root system explores the small volume of existing soil more intensely, as there is an overlap of the depletion zones, especially of $\mathrm{P}$ around the roots, which hardly happens in the field (STAHL et al., 2013).

There were no superior responses in treatments with liming. In most treatments the means of the morphological variables obtained with the presence of liming were lower when compared to the treatments without liming. Only in the treatments with the highest $\mathrm{K}$ dosage, the means obtained were higher than in the absence of liming, indicating that for the soil and species conditions of this study, liming did not affect the growth of morphological variables. Probably this response is due to the soil having the necessary $\mathrm{Ca}$ and mainly $\mathrm{Mg}$ reserves (main nutrients required) to supply the beginning of seedling development. It is important to highlight that the liming was carried out at the same time as the fertilization, and in many cultures the recommendation is to do it beforehand. For Eucalyptus cultivation, mainly in the reform area (area with old planting), liming when applied is applied just before the time of planting the seedlings. Liming before phosphate fertilization can also decrease the capacity for adsorption or fixation of $\mathrm{P}$ by the soil (RAIJ, 1992).

\section{Physiological variables}

For physiological variables the result showed a more homogeneous behavior for treatment with the recommended dosages for N, P and K (150200-150) in the presence or absence of liming. In general, it was not possible to find a relationship between the growth of eucalyptus trees and photosynthetic rates. OTTO et al. (2013) highlighted that this absence of relationship can occur, at least in part, because the evaluations of the variables happen in distinct moments, that is, the growth is the result of a continuous process that results in the accumulation of biomass, while the photosynthesis evaluation is carried out on a specific occasion during the growth of the plant.

No significant influence was observed for the suppression of $\mathrm{N}$ and $\mathrm{P}$ elements in the treatments. To $\mathrm{N}$, this result can be explained by the OM content in the soil; which although not ideal, meets the basic requirements of the genus (PERDOMO et al., 2007). Nitrogen is one of the macronutrients that most influences photosynthesis in forest species. In some species, fertilization with $\mathrm{N}$ caused a decrease in photosynthesis as in E. grandis (CLEARWATER \& MEINZER, 2001), Pinus sylvestris (SMOLANDER \& OKER-BLOM, 1989), P. taeda (GREEN \& MITCHELL, 1992), but did not increase photosynthesis in E. nitens (FORRESTER et al., 2012) and E. globulus (TURNBULL et al., 2007).

For treatment with twice the recommended dose for N (300-200-150) with liming there was also significant response when compared to treatment without liming. The addition of $\mathrm{N}$ promotes formation of active photosynthetic pigments and participates in 
processes such as ionic absorption, photosynthesis, respiration, multiplication and cell differentiation (TEIXEIRA FILHO et al., 2011). The highest dosages of NPK the response was also positive with the presence of liming. But this in practice, as previously discussed, would not be applicable, due to the increase in costs and environmental problems.

Treatment with $\mathrm{K}$ suppression in the absence of liming was directly influenced in the decrease in physiological variables. According to DECHEN \& NACHTIGALL (2007), in the absence of $\mathrm{K}$, the plant presents reduced photosynthesis and increased respiration. These two conditions (reduction in photosynthesis and increase in plant respiration), when there is a $\mathrm{K}$ deficiency, reduce the accumulation of carbohydrates, resulting in reduced plant growth. The lower photosynthetic performance in plants with $\mathrm{K}$ deficiency is related to stomatal opening not happening on a regular basis, reducing the entry of $\mathrm{CO}_{2}$ (PRADO, 2008).

According to VIEIRA et al. (2016), one of the most required nutrients in the production of shoot dry mass is K. Due to the authors' assumption, the decrease in physiological activities may be related to the lack of $\mathrm{K}$ in one of the treatments (150-200-0) with greater influence on the decrease of physiological activities. Potassium can confer an adequate dynamic of stomatal conductance to plants, besides being an extremely important element in the activation of Rubisco's carboxylase function, which contributes to greater photosynthetic activity (PRADO, 2008).

In general the treatment that did not change with the presence or absence of liming for physiological responses was the treatment with the recommended dose (150-200-150), assuming that in relation to the physiological activity of the species under the conditions of this study, this is the best treatment. This treatment also showed good responses in the morphological variables, such as $\mathrm{SD}$ and $\mathrm{H}$, and this treatment can be recommended as the most appropriate in the initial growth of E. benthamii when balancing physiological and morphological variables.

\section{CONCLUSION}

The absence of $\mathrm{N}$ negatively affected the means of the morphological variables and there was a direct relationship between increasing the dose and increasing the means. The increase in $\mathrm{P}$ also increased some variables such as SDMC and RDMC. K did not promote changes in morphological variables.
For physiological variables, the absence of fertilization or very high doses caused a decrease in photosynthesis. Higher doses of $\mathrm{K}$ caused a decrease in photosynthesis and stomatal conductance. Except for the treatment without $\mathrm{K}$, in which liming increased the averages of physiological variables, the other doses of NPK showed no difference with the addition of liming. In general, the dosage 150-200-150 showed the best result for the physiological variables.

Based on the recommendations for each situation exposed in the study, to meet the morphological and physiological demands, the recommendation for cultivation of $E$. benthamii under the conditions of this study is the doses 150 200-150, without liming application.

\section{ACKNOWLEDGEMENTS}

The authors thank the Universidade do Estado de Santa Catarina (UDESC), for the institutional support for this research. To FAPESC for funding the research group Management of Planted and Natural Forests (PAP2019031000055) and Coordenação de Aperfeiçoamento de Pessoal de Nível Superior (CAPES) for partial finance support, Brasil - Finance code 001.

\section{DECLARATION OF CONFLICT OF INTEREST}

The authors declare no conflict of interest. The founding sponsors had no role in the design of the study; in the collection, analyses, or interpretation of data; in the writing of the manuscript, and in the decision to publish the results.

\section{AUTHORS' CONTRIBUTIONS}

The authors contributed equally to the manuscript. All authors critically revised the manuscript and approved of the final version.

\section{REFERENCES}

ALVARES, C. A. et al. Köppen's climate classification map for Brazil. Meteorologische Zeitschrift, v.22, n.6, p.711-728, 2013. Available from: $<$ https://www.researchgate.net/publication/263088914 Koppen\%27s_climate_classification_map_for_Brazil $>$. Accessed: Sep. 09, 2020. doi: 10.1127/0941-2948/2013/0507.

ARNOLD, R. et al. Selection of cold-tolerant Eucalyptus species and provenances for inland frost-susceptible, humid subtropical regions of southern China. Australian Forestry, v.78, n.3, p.180193, 2015. Available from: <https://www.tandfonline.com/doi/abs/ 10.1080/00049158.2015.1063471>. Accessed: Sep. 08, 2020. doi: $10.1080 / 00049158.2015 .1063471$.

BAYLE, G. Ecological and social impacts of Eucalyptus tree plantation on the environment. Journal of Biodiversity Conservation and Bioresource Management, v.5, n.1, p.93-104, 2019. Available from: $<$ https://www.banglajol.info/index.php/jbcbm/article/view/42189>. Accessed: Sep. 08, 2020. doi: 10.3329/jbcbm.v5i1.42189. 
CLEARWATER, M. J.; MEINZER, F. C. Relationships between hydraulic architecture and leaf photosynthetic capacity in nitrogenfertilized Eucalyptus grandis trees. Tree Physiology, v.21, n.10, p.683-690, 2001. Available from: <https://academic.oup.com/ treephys/article/21/10/683/1735476>. Accessed: Sep. 08, 2020. doi: $10.1093 /$ treephys/21.10.683.

CUNHA, C. O. M. et al. Crescimento e qualidade de mudas de Citharexylum myrianthum em resposta à fertilização nitrogenada. Advances in Forestry Science, v.6, n.1, p.507-513, 2019. Available from: <http://periodicoscientificos.ufmt.br/ojs/index. php/afor/article/view/6433/pdf >. Accessed: May, 13, 2019. doi: 10.34062/afs.v6i1.6433.

DECHEN, A. R.; NACHTIGALL, G. R. Elementos requeridos à nutrição de plantas. Viçosa: SBCS, 21p. 2007. Available from: <http:// ainfo.cnptia.embrapa.br/digital/bitstream/item/202931/1/92682007-p.91-132.pdf>. Accessed: Jul. 03, 2019.

DIAS, L. P. R. et al. Partial substitution of soluble phosphate by rock phosphate in the planting of Eucalyptus benthamii and Eucalyptus dunnii in southern Brazil. Revista Brasileira de Ciência do Solo, v.38, n.2, p.516-523, 2014. Available from: <https://www.scielo. br/pdf/rbcs/v38n2/16.pdf >. Accessed: Sep. 07, 2020. doi: 10.1590/ S0100-06832014000200016.

DICKSON, A. et al. Quality appraisal of white spruce and white pine seedling stock in nurseries. Forestry Chronicle, v.36, p.10-13, 1960. Available from: <https://pubs.cif-ifc.org/doi/ pdf/10.5558/tfc36010-1>. Accessed: Sep. 07, 2020. doi: 10.5558/ tfc36010-1.

FERREIRA, D. F. Sisvar: A computer analysis system to fixed effects split plot type designs. Revista Brasileira de Biometria, [S.1.], v.37, n.4, p.529-535, 2019. Available from: <http://www. biometria.ufla.br/index.php/BBJ/article/view/450>. Accessed: Feb. 10, 2020. doi: 10.28951/rbb.v37i4.450.

FORRESTER, D. I. et al. Effect of thinning, pruning and nitrogen fertilizer application on transpiration, photosynthesis and wateruse efficiency in a young Eucalyptus nitens plantation. Forest Ecology and Management, v.266, p.286-300, 2012. Available from: <https://www.sciencedirect.com/science/article/abs/pii/ S0378112711007043>. Accessed: Sep. 08, 2020. doi: 10.1016/j. foreco.2011.11.019.

GAVA, J. L. Efeito da adubação potássica em plantios de Eucalyptus grandis conduzidos em segunda rotação em solos com diferentes teores de potássio trocável. Série Técnica IPEF, v.11, n.30, p.84-94. 1997.

GONZALEZ, R. et al. Exploring the potential of Eucalyptus for energy production in the Southern United States: Financial analysis of delivered biomass. Biomass Bioenergy, v.35, n.2, p.755-766, 2018. Available from: <https://www.researchgate.net/ publication/223431196_Exploring_the_potential_of_Eucalyptus for_energy_production_in_the_Southern_United_States Financial analysis of delivered biomass Part I $>$. Accessed: Sep. 07, 2020. doi: $10.1016 /$ j.biombioe. 2010.10 .011 .

GREEN, T. H.; MITCHELL, R. J. Effects of nitrogen on the response of Loblolly Pine to water strees. I. Photosynthesis and stomatal conductance. New Phytologist, v.122, n.4, 627-633, 1992. Available from: <https://nph.onlinelibrary.wiley.com/doi/ abs/10.1111/j.1469-8137.1992.tb00090.x>. Accessed: Sep. 08, 2020. doi: 10.1111/j.1469-8137.1992.tb00090.x.
LORENTZ, K. A.; MINOGUE, P. J. Exotic Eucalyptus plantations in the southeastern US: Risk assessment, management and policy approaches. Biological Invasions, v. 17, n.1, p.1581-1593, 2015. Available from: $<$ https://link.springer.com/article/10.1007/s10530015-0844-0>. Accessed: Sep. 07, 2020. doi: 10.1007/s10530-0150844-0.

MAEDA, S.; BOGNOLA, I. A. Influence of lime and phosphorus in initial growth of eucalyptus and in $\mathrm{P}$ critical level. Pesquisa Florestal Brasileira, v.32, n.72, p.401-407, 2012. Available from: $\quad<$ https://pfb.cnpf.embrapa.br/pfb/index.php/pfb/article/ view/305/284>. Accessed: Dec. 10, 2019. doi: 10.4336/2012. pfb.32.72.401.

MAIER, C. A. et al. Comparative water use in short-rotation Eucalyptus benthamii and Pinus taeda trees in the Southern United States. Forest Ecology and Management, v.397, n.1, p.126-138, 2017. Available from: <https://www.sciencedirect.com/science/ article/abs/pii/S0378112716307058>. Accessed: Sep. 07, 2020. doi: 10.1016/j.foreco.2017.04.038.

MALAVOLTA, E. et al. Avaliação do Estado Nutricional das Plantas: princípios e aplicações. 2.ed. Piracicaba: Associação Brasileira para Pesquisa da Potássio e do Fosfato, 1997. 319p.

MATOS, F. S. et al. Influence of light intensity on the development of seedlings Jatropha curcas L. Agrarian, v.4, n.14, p.265-272, 2011. Available from: <http://ojs.ufgd.edu. br/index.php/agrarian/article/view/1226>. Accessed: Sep. $09,2020$.

MENEGHETTE, H. H. A. et al. Doses of phosphorus and potassium in peanut plant in the presence and absence of foliar fertilization. Brazilian Journal of Biosystems Engineering, v.11, n.2, p.125-134, 2017. Available from: <http://seer.tupa.unesp.br/ index.php/BIOENG/article/view/513/325>. Accessed: Sep. 07, 2020. doi: 10.18011/bioeng2017v11n2p125-134.

NAVROSKI, M. C. et al. Hidrogel enables use of reduction of irrigation and improves the inicial grownth of Eucalyptus dunnii Maiden seedlings. Scientia Forestalis, v.43, n.106, p.467-476, 2015. Available from: <https://www.ipef.br/publicacoes/scientia/ nr106/cap22.pdf>. Accessed: Dec. 10, 2019

NOVAIS, R. F. et al. Fósforo. In: NOVAIS, R. F. et al. Fertilidade do solo. Viçosa, MG, Sociedade Brasileira de Ciência do Solo, 2007. p.471-537.

OTTO, M. S. G. et al. Photosynthesis, stomatal conductance and productivity of Eucalyptus clones under different soil and climatica conditions. Revista Árvore, v.37, n.3, p.431-439, 2013. Available from: <https://www.scielo.br/pdf/rarv/v37n3/ a06v37n3.pdf>. Accessed: Sep. 09, 2020. doi: 10.1590/S010067622013000300006

PERDOMO, C. et al. Soil and plant indices for predicting eucalypt response to nitrogen in Uruguay. Soil Fertility \& Plant Nutrition, v.71, n.6, p.1708-1718, 2007. Available from: <https://acsess.onlinelibrary.wiley.com/doi/abs/10.2136/ sssaj2006.0288>. Accessed: Sep. 09, 2020. doi: 10.2136/ sssaj2006.0288.

PRADO, L. M. et al. Macronutrient deficiencies in soybean cv. BRSMG 68 (Vencedora) cultivated in nutritive solution. Comunicata Scientiae, v.1, n.2, p.114-119, 2010. Available from: $<$ http://www.nutricaodeplantas.agr.br/site/downloads/unesp_ 
jaboticabal/omissao_soja9.pdf>. Accessed: Sep. 21, 2019. doi: 10.14295/cs.v1i2.48.

PRADO, R. M. Nutrição de plantas. São Paulo: UNESP, 407p. 2008.

RAIJ, B. et al. Adubação fosfatada no Brasil. Planaltina: EMBRAPA, CPAC, 1992. 326p. (Documentos, 21).

ROS, C. O. et al. Initial growth of mixed stands of Eucalyptus grandis Hill ex Maiden and Toona ciliata M. Roem var. australis with suppression of primary macronutrients. Scientia Forestalis, v.44, n.111, p.769-777, 2016. Available from: <https:// pdfs.semanticscholar.org/d1 f9/2b35cf72afa73f9c8e98a8f0e0 548085599b.pdf?_ga=2.98561692.2022405183.159172492146106810.1591724921>. Accessed: Nov. 10, 2019. doi: 10.18671/ scifor.v44n111.23.

SILVA, A. et al. Evaluation of application of basalt powder effects in soil fertility and Eucalyptus benthamii nutrition. Floresta, v.42, n.1, p.69-76, 2012. Available from: <https://revistas.ufpr.br/ floresta/article/view/26300/17501>. Accessed: Feb. 01, 2019. doi: $10.5380 /$ rf.v42i1.26300.

SILVA, W. et al. Transpiratory rate of eucalypt seedlings in response to water levels in the soil and to association with brachiaria. Pesquisa Agropecuária Brasileira, v.35, n.5, p.923928. 2000. Available from: <https://www.scielo.br/pdf/pab/ v35n5/4713.pdf>. Accessed: Sep. 08, 2020. doi: 10.1590/S0100204X2000000500009.

SMETHURST, P. et al. Nitrogen management in Eucalyptus nitens plantations. Forest Ecology and Management, v.193, p.63-80, 2004. Available from: <https://www.sciencedirect.com/science/ article/abs/pii/S0378112704000507>. Accessed: Sep. 09, 2020. doi: 10.1016/j.foreco.2004.01.023.

SMOLANDER, H.; OKER-BLOM, P. The effect of nitrogen content on the photosynthesis of Scots pine needles and shoots. Annales des Sciences Forestières, v.46 (Suppl.) p.473-475, 1989 Available from: <https://hal.archives-ouvertes.fr/hal-00882596/ document>. Accessed: Sep. 07, 2020.

SOUZA, S. R.; FERNANDES, M. S. Nitrogênio. In: FERNANDES, M. S. Nutrição mineral de plantas. Viçosa: Sociedade Brasileira de Ciência do Solo, 2006. p.215-252.
STAHL, J. et al. Dry matter yield and nutritional efficiency of Eucalyptus benthamii and Eucalyptus dunnii clones due to addition of phosphorus rates to the soil. Ciência Florestal, v.23, n.2, p.287-295, 2013. Available from: <https://www.scielo.br/pdf/ cflo/v23n2/1980-5098-cflo-23-02-00287.pdf > . Accessed: Feb. 01, 2020. doi: $10.5902 / 198050989275$.

STANTURF, J. A. et al. Eucalyptus beyond its native range: Environmental issues in exotic bioenergy plantations. International Journal of Forestry Research, v.2013, n.1, ID. 463030, 2013. Available from: <https://www.hindawi.com/ journals/ijfr/2013/463030/>. Accessed: Sep. 09, 2020. doi: $10.1155 / 2013 / 463030$

TEIXEIRA FILHO, M. C. M. Application times, sources and doses of nitrogen on wheat cultivars under no till in the Cerrado region. Ciência Rural, v.41, n.8, p.1375-1382, 2011. Available from: $<$ https://www.scielo.br/pdf/cr/v41n8/a7711cr2950.pdf $>$. Accessed: Feb. 10, 2020. doi: 10.1590/S0103-84782011000800013.

TURNBULL, T. L. et al. Within-canopy nitrogen and photosynthetic gradients are unaffected by soil fertility in fieldgrown Eucalyptus globulus. Tree Physiology, v.27, n.11, p.16071617, 2007. Available from: <https://academic.oup.com/treephys/ article/27/11/1607/1672782>. Accessed: Sep. 08, 2020. doi: 10.1093/treephys/27.11.1607.

VIÉGAS, I. J. M. et al. Visual symptoms, growth and nutrients of Alpinia purpurata plants exposed to $\mathrm{N}, \mathrm{P}, \mathrm{K}, \mathrm{Ca}, \mathrm{Mg}$ and $\mathrm{S}$ deficiencies. Journal of Food, Agriculture \& Environment, v.9, n.(3\&4), p.1048-1051, 2011. Available from: <https://pdfs. semanticscholar.org/2b12/c29b27078a6175e5b3e5d6d901183ca7da54. pdf $>$. Accessed: Sep. 07, 2020

VIEIRA, M. S. et al. Potassium supply capacity of twelve soil classes in function of maize successive crops. Revista Ciências Agrárias, v.59, n.3, p.219-227, 2016. Available from: <http:// periodicos.ufra.edu.br/index.php/ajaes/article/view/1910/866>. Accessed: Nov. 10, 2019. doi: 10.4322/rca.1910.

WYNGAARD, N. et al. Fertilization and tillage effects on soil properties and maize yield in a Southern Pampas Argiudoll. Soil Soil \& Tillage Research, v.119, p.22-30, 2012. Available from: <https:// www.sciencedirect.com/science/article/pii/S0167198711002303>. Accessed: Sep. 08, 2020. doi: 10.1016/j.still.2011.12.002. 